University of Nebraska - Lincoln

DigitalCommons@University of Nebraska - Lincoln

2006

\title{
Comparison of breeding bird and vegetation communities in primary and secondary forests of Great Smoky Mountains National Park
}

Theodore R. Simons

North Carolina State University, tsimons@ncsu.edu

Susan A. Shriner

Colorado State University, susan.a.shriner@aphis.usda.gov

George L. Farnsworth

Xavier University - Cincinnati, Farnsworth@xavier.edu

Follow this and additional works at: https://digitalcommons.unl.edu/usgsstaffpub

Simons, Theodore R.; Shriner, Susan A.; and Farnsworth, George L., "Comparison of breeding bird and vegetation communities in primary and secondary forests of Great Smoky Mountains National Park" (2006). USGS Staff -- Published Research. 570.

https://digitalcommons.unl.edu/usgsstaffpub/570

This Article is brought to you for free and open access by the US Geological Survey at DigitalCommons@University of Nebraska - Lincoln. It has been accepted for inclusion in USGS Staff -- Published Research by an authorized administrator of DigitalCommons@University of Nebraska - Lincoln. 


\title{
Comparison of breeding bird and vegetation communities in primary and secondary forests of Great Smoky Mountains National Park
}

\author{
Theodore R. Simons*, Susan A. Shriner ${ }^{1}$, George L. Farnsworth ${ }^{2}$ \\ USGS, North Carolina Cooperative Fish and Wildlife Research Unit, Department of Zoology, Campus Box 7617 NCSU, North \\ Carolina State University, Raleigh, NC 27695, United States
}

\section{A R T I C L E I N F O}

Article history:

Received 27 October 2004

Received in revised form

28 October 2005

Accepted 31 October 2005

Available online 21 February 2006

\section{Keywords:}

Primary forest

Old-growth

Secondary forest

Second-growth

Birds

Great Smoky Mountains National

Park

Southern appalachians

Detection probability

\begin{abstract}
A B S T R A C T
We compared breeding bird communities and vegetation characteristics at paired point locations in primary (undisturbed) and mature secondary forest (70-100 years old) sites in Great Smoky Mountains National Park, USA to understand how sites logged prior to creation of the park compare to undisturbed sites following 70 years of protection from human disturbance. We found that bird and vegetation communities are currently similar, but retain some differences in species composition. Rank abundance curves for primary and secondary forest bird communities showed very similar patterns of species dominance. Species composition was also similar on the two sites which shared 24 of the 25 most frequently recorded species. Nonetheless, comparisons of density estimates derived from distance sampling showed three bird species were more abundant on primary forest sites and that one bird species was significantly more abundant on secondary forest sites. Notably, comparisons based on raw counts (unadjusted for potential differences in detectability) produced somewhat different results. Analyses of vegetation samples for the paired sites also showed relative similarity, but with some differences between primary and secondary forests. Primary forest sites had more large trees (trees greater than $50 \mathrm{~cm}$ diameter at breast height) and late successional species. Primary forest sites had a denser tall shrub layer while secondary forest sites had a denser canopy layer. Nonetheless, tree species richness, basal area of live trees and number of standing snags did not differ between primary and secondary forest sites. Results indicate that breeding bird communities on sites within the park that were logged commercially 70 years ago are currently quite similar to bird communities on sites with no history of human disturbance. Similarities between the bird communities on previously disturbed and undisturbed sites in Great Smoky Mountains National Park may exceed those on more fragmented landscapes because large patches of primary forest, adjacent to commercially logged sites, remained in the park when it was established in 1935. These patches of primary forest may have served as source areas for commercially logged sites.
\end{abstract}

Published by Elsevier Ltd.

\footnotetext{
* Corresponding author: Tel.: +1 919515 2689; fax: +1 9195154454.

E-mail address: tsimons@ncsu.edu (T.R. Simons).

${ }^{1}$ Present address: Department of Fishery and Wildlife Biology, Colorado State University, Fort Collins, CO 80523, United States.

2 Present address: Department of Biology, Xavier University, 3800 Victory Parkway, Cincinnati, OH 45207, United States. 0006-3207/\$ - see front matter. Published by Elsevier Ltd. 


\section{Introduction}

Many studies have documented differences in animal species community structure and composition on old-growth and second-growth forest sites (e.g., Haney, 1999; Jung et al., 1999; Okland, 1996; Thompson et al., 1999; Lomolino and Perault, 2000; Martikainen et al., 2000; Blake and Loiselle, 2001; Hyde and Simons, 2001). Similarly, many studies have investigated animal community responses to silvicultural practices (e.g., Morrison, 1992; Herbeck and Larsen, 1999; Sallabanks et al., 2000). Most comparative studies have focused on differences between early second-growth and old-growth, or early and late second-growth forests (e.g., Diaz et al., 2005). Comparative studies are often constrained by a lack of replication and the difficulty of pairing small and widely scattered remnants of old forest with comparable sites that have regenerated from previous clearing. Few studies have examined animal community differences between undisturbed primary forest and mature second-growth forests (but see Herbeck and Larsen, 1999; Hyde and Simons, 2001). Such comparisons are an important step in identifying the point at which wildlife species no longer discriminate habitat differences associated with historic land use.

Animal community differences along successional gradients are generally attributed to changes in vegetation structure and composition (Thompson et al., 1999, 2003). Comparisons of old-growth and mature second-growth temperate forests have shown that forests regenerated over the last century have developed many of the structural characteristics of old-growth (Schuler and Gillespie, 2000; Ziegler, 2000). Despite measurable differences between old-growth and second-growth forests, there is no general agreement on a definition of old-growth (Leverett, 1996; White and White, 1996). Assigning an age-based definition is problematic because different forest types are dominated by species with differing life history parameters. Furthermore, researchers do not agree on whether or not forests that have undergone widespread natural disturbance, but have not been altered by human disturbance, should be defined as old-growth (Leverett, 1996; White and White, 1996). White and White (1996) argue that forests that are relatively young due to natural disturbance should be considered old-growth because they contain undisturbed soils and characteristic amounts of coarse woody debris, and because such forests are important and natural elements of old-growth forest mosaics. Moreover, Runkle (2000) showed that while undisturbed old-growth forests in the eastern United States change very slowly over time, they are always in a state of flux.

Despite these issues, most researchers agree on the general characteristics of old-growth forests, such as old trees, large trees, woody debris, high density of snags, canopy gaps, pits and mounds, identifiable growth layers, late successional species, and lack of human disturbance (Leverett, 1996). These features provide unique structural habitat characteristics that have been identified in several studies as offering optimum conditions for North American bird species such as Red-breasted Nuthatch (Sitta canadensis), Brown Creeper (Certhia americana), Winter Wren (Troglodytes troglodytes), and Golden-crowned Kinglet (Regulus satrapa) (Haney et al., 2001), as well as the Rufus Treecreeper (Climacteris rufa) in western Australia (Luck, 2002), and the Eurasian Treecreeper (Certhia familiaris) in central Finland (Suorsa et al., 2005).

Great Smoky Mountains National Park, USA includes more than 45,000 ha of primary forest that lack evidence of direct human disturbance from timber harvest, settlement, or agriculture (Pyle, 1985; Davis, 1996). Although these forests are considered old-growth, most areas have been subject to large scale natural disturbances at some point in the past. Natural disturbances have included extensive fire, windstorms, ice and snow storms, landslides, and insect outbreaks (SAMAB, 1996; Greenberg and McNab, 1998). Furthermore, exotic pests and the loss of predators have influenced forest structure and composition. Invasions of chestnut blight (Endothia parasitica) and balsam woolly adelgid (Adelges piceae) have led to the eradication of American chestnut (Castanea dentata) and Fraser fir (Abies fraseri) as canopy trees in most forests of the southeast (Liebhold et al., 1995). The loss of large predators and subsequent increases in deer and feral hog populations have altered understory communities (SAMAB, 1996). Nonetheless, these forests retain essential qualities of primary forest (Busing, 1998) and are characterized by diverse plant and animal populations. Great Smoky Mountains National Park, like much of the southern Appalachians region, also contains forests regenerating from the extensive industrial logging that took place in the early part of the twentieth century (Pyle, 1985; SAMAB, 1996; Yarnell, 1998).

Hyde and Simons (2001) showed that salamander populations are more abundant and salamander communities are more diverse on undisturbed sites compared to mature second-growth sites in Great Smoky Mountains National Park. Furthermore, several salamander species show strong positive associations with undisturbed sites. While no similar study has been conducted on breeding birds in the southern Appalachians, Haney (1999) documented increased abundance of several bird species in old-growth forests of the Allegheny Plateau in Pennsylvania, USA compared with the surrounding landscape.

In this paper we report on breeding bird community structure and composition in primary forest (undisturbed oldgrowth) and mature secondary forest (70-100 years post logging) in Great Smoky Mountains National Park. We compare the two forest types to investigate whether bird communities on mature second-growth sites are indistinguishable from those on undisturbed sites, or if community differences continue to persist after 70-100 years of regeneration. Similarly, we evaluate vegetation composition and structure to identify factors potentially associated with differences in bird communities. We also discuss the importance of adjusting for differential detectability when point count surveys are used to compare breeding bird communities in different habitats. Although increasing attention has been focused on the need to use sampling and analytic methods that account for habitat or species-specific differences in detection probabilities (Buckland et al., 1993; Lancia et al., 1994; Thompson et al., 1998; Yoccoz et al., 2001; Rosenstock et al., 2002), relatively few studies (e.g., Boulinier et al., 2001) incorporate such methods, and none have demonstrated habitat specific differences in detection probabilities. 


\section{Methods}

\subsection{Study area}

The southern Appalachians region of the southeastern United States is an area of nearly 15 million ha extending from northern West Virginia and Virginia southwest to northern Alabama and Georgia (SAMAB, 1996). Much of the region was cleared as a result of industrial logging in the early twentieth century (Yarnell, 1998). The area is now $70 \%$ forested as a result of reforestation over the last century. Current forest composition in the southern Appalachians reflects a history of logging, fire suppression, settlement, and invasions of chestnut blight and balsam woolly adelgid.

We sampled vegetation and bird communities in Great Smoky Mountains National Park $\left(35^{\circ} 37^{\prime} \mathrm{N}, 83^{\circ} 53^{\prime} \mathrm{W}\right)$ which serves as the nucleus of a group of publicly owned protected areas in the southern Appalachians, including more than 2 million ha of National Forests, federally designated wilderness areas, state lands, Tennessee Valley Authority reservoirs, and National Parks. The park, located along the border between North Carolina and Tennessee (Simons et al., 2000), is an International Biosphere Reserve and World Heritage Site. It is the largest National Park, and the largest federal wilderness area in the eastern United States (Johnson et al., 2000).

When established in 1935, over three quarters of Great Smoky Mountains National Park had been cleared by humans for timber harvest and settlement (Pyle, 1985) (Fig. 1). Highly mechanized industrial logging from 1900 to 1930 created extensive clear cuts that resulted in significant soil erosion (Pyle, 1985). The 23\% of the park that has no history of logging or clearing by humans represents the largest contiguous tract of primary forest in the eastern US (Davis, 1996). Logged sites have regenerated since the park was established and today more than $95 \%$ of the approximately 205,000 ha park is forested.
Great Smoky Mountains National Park is characterized by wide elevational gradients (575-1830 m) and complex topography which support a rich diversity of habitat and vegetation types. More than half the park is deciduous mesic hardwoods, with spruce-fir and northern hardwoods found at the highest elevations, and xeric deciduous hardwoods, evergreen pines, and areas of mixed hardwoods and pines found at lower elevations.

\subsection{Bird surveys}

We conducted 7535 variable circular plot point transects (Reynolds et al., 1980) at 4157 point locations from mid-May to the end of June during 1996-1999 for a park-wide inventory of breeding birds (Shriner, 2001; Shriner et al., 2002). We established points approximately $250 \mathrm{~m}$ apart throughout the park. Most (>95\%) points were established on low-use hiking trails, although some were located on low-traffic roads or off-trail transects. We recorded a location for each point using a differentially corrected global positioning system (GPS) (GeoExplorer II; Trimble Navigation 1996). Surveys followed protocols recommended by Ralph et al. (1995), recording all birds seen or heard during 10 minute counts conducted between sunrise and 10:15 AM in favorable weather. We recorded the horizontal distance from the observer to each bird detected. We used a laser range finder (Bushnell, Yardage Pro $400^{\mathrm{TM}}$ ) to aid in distance estimation by sighting a $50-\mathrm{m}$ radius circle prior to each survey. At each point we also recorded the time of day and scored levels of background noise (generally a function of stream noise) using a 5-category index.

\subsection{Vegetation surveys}

We sampled vegetation in $10 \mathrm{~m}$ radius plots at each of the 4157 bird point count locations. For bird points along trails or roads, we shifted vegetation plots $10 \mathrm{~m}$ away from point

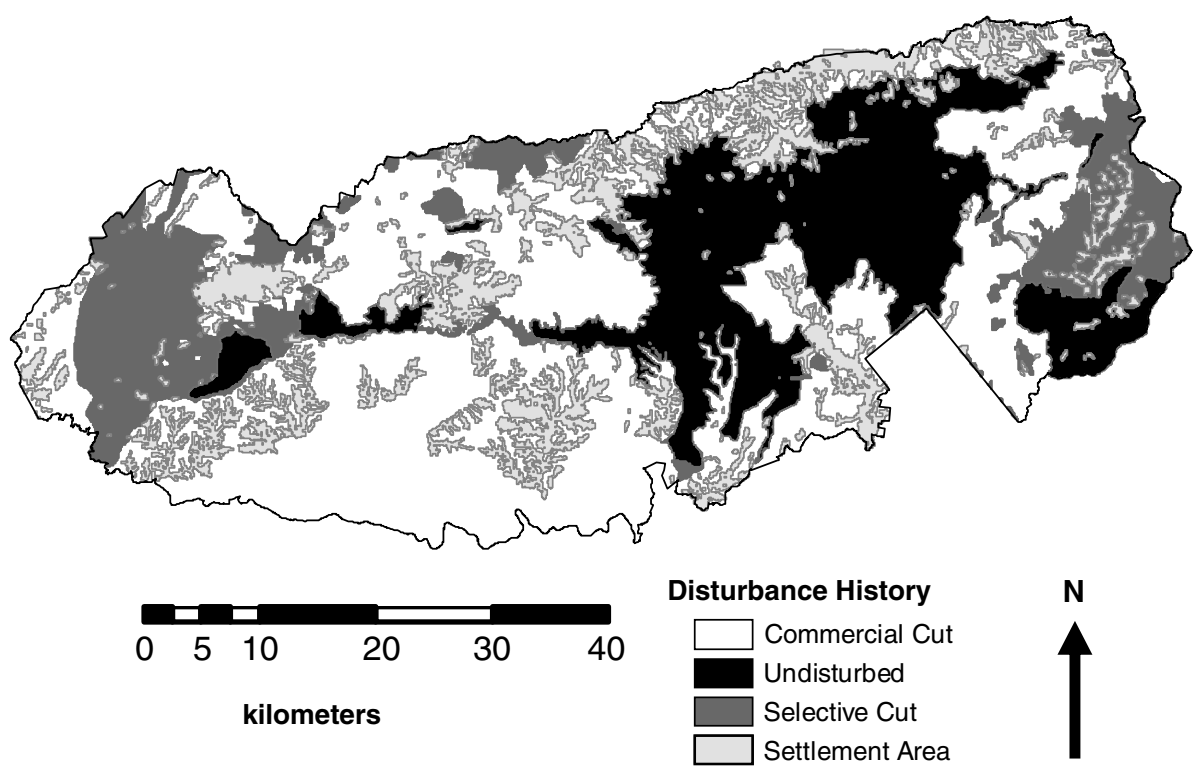

Fig. 1 - Disturbance history of Great Smoky Mountains National Park (Pyle, 1985). Comparisons of primary and secondary forest communities were restricted to survey locations in either undisturbed primary forest (black) or secondary forests that have re-grown following commercial logging (white). 
centers, tossing a coin to determine which side of the road or trail to sample; off-trail points were sampled at bird point count centers. We visually estimated percent cover (defined as percent foliage blocking sunlight to layers below) for five vegetation layers (tree canopy, subcanopy, tall shrub, low shrub/seedling, and herbaceous) and assigned each layer to one of the following percent cover classes: <0.1, 0.1-1, 1-2, $2-5,5-10,10-25,25-50,50-75,75-95,>95$. We estimated height ranges for each layer, using laser range finders to determine the height of the tallest tree in canopy and subcanopy layers. We determined species composition of canopy, subcanopy, and tall shrub layers by identifying species within each layer, and visually estimated species-specific percent contribution to the layer. We also used a wedge prism (basal area factor 20 , Avery and Burkhart, 1983) at the center of each vegetation plot to sample trees. Wedge prism samples are plotless so we included all individuals detected in the wedge prism regardless of distance. We identified all trees observed in the wedge prism sample, and visually assigned each tree to one of six dbh (diameter at breast height) classes: 0-10, 11-25, 26-50, 51-75, 76-100 and $>100 \mathrm{~cm}$.

\subsection{Paired point selection}

We limited our analyses to survey points located in either undisturbed primary forest or commercially logged secondary forest (Fig. 1). In an effort to eliminate possible effects of site covariates on community comparisons, we paired primary and secondary forest survey points according to the following selection criteria. We first identified a pool of secondary forest points that matched primary forest points based on vegetation community type, census date (within 14 days), time (within $2 \mathrm{~h}$ ), and background noise (within 1 noise level). From the pool of points that met these criteria we paired primary and secondary forest points by minimizing elevational differences. Although we allowed a maximum difference of $150 \mathrm{~m}$, the paired points had an average elevation difference less than $30 \mathrm{~m}$. We limited pair selection to vegetation types that were represented by at least 30 pairs of points (cove hardwood, mixed mesic hardwood, and northern hardwood), identifying 247 sample pairs that met these selection criteria.

\subsection{Bird communities}

We compared bird communities in primary and secondary forests using measures of relative abundance and density. We tested for differences using two-tailed paired t-tests (Zar, 1999). We compared the number of detections per point for individual species from primary forest locations with those from secondary forest locations. We also plotted rank abundance curves (Magurran, 1988) for the two forest samples using the percent of the total sample for each species as its index of abundance.

Because we were concerned about differential detectability of birds in primary forest sites compared to secondary forest sites, we estimated effective detection radii (EDR) for each bird species in each habitat type using Program DISTANCE (Thomas et al., 1998). Program DISTANCE is appropriate for use with distance sampling data in which observations are accompanied by an estimate of distance from the observer.
The EDR is approximately the distance at which the probability of detection declines to one half, depending on the function used to model detectability as a function of distance (Laake et al., 1993). We compared EDR estimates for each species to identify differences in detectability between primary and secondary forest sites. Program DISTANCE uses a maximum likelihood based function of detection and distance to estimate a sample density. We compared density estimates using z-tests, and we limited our analyses to species for which we had a minimum of 75 detections on both primary and secondary forest sites.

\subsection{Vegetation communities}

We compared per plot coverage estimates for three vegetation layers (canopy, subcanopy, and tall shrub) on primary and secondary sites using paired t-tests (233 paired plots, a subset of the 247 paired bird points for which we had complete data). We used the midpoint of the field estimated cover class at each point as our cover estimate. We evaluated species-specific differences between the two communities (for canopy, subcanopy, and tall shrub layers) by comparing per plot importance values for individual species using paired t-tests. We calculated importance values by multiplying the percent contribution of each species by the midpoint of the cover class. We assessed tree size distribution with wedge prism data for 191 paired plots by summing the number of stems counted in each dbh class for the primary and secondary forest samples. We also tested for differences in the number of snags by comparing the per plot number of standing snags counted in the wedge prism samples for primary and secondary forest plots.

\section{Results}

\subsection{Bird communities}

We detected 4757 individual birds of 68 species on the 247 paired point transects (494 total points). We observed 2406 individuals of 56 species on primary forest sites and 2351 individuals of 66 species on secondary forest sites (Appendix). Twelve species were limited to secondary forest sites, two species were detected only on primary forest sites, and 54 species were observed on both forest types. Rank-abundance plots for primary and secondary forest sites indicate that the bird community structure was very similar at the two sites (Fig. 2).

Paired comparisons of unadjusted counts showed Winter Wren and Black-throated Blue Warbler (Dendroica caerulescens) were recorded significantly more frequently on primary forest sites compared to secondary forest sites. Black-throated Green Warbler (Dendroica virens) was recorded significantly more frequently on secondary forest sites (Fig. 3). Effective detection radii (EDR) varied between primary and secondary forest habitats for individual bird species with significant differences for three species (Fig. 3). Dark-eyed Junco (Junco hyemalis), Winter Wren, and Blue-headed Vireo (Vireo solitarius) had significantly lower EDR on primary forest sites than on secondary forest. In nine of the 10 species with a minimum of 75 detections in both primary and secondary forests, 


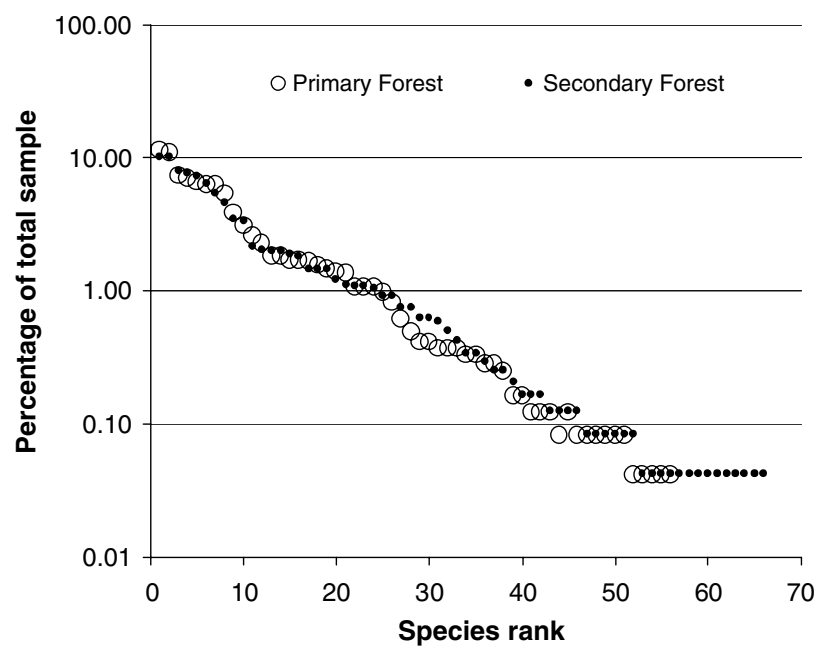

Fig. 2 - Rank abundance plot for unadjusted counts of breeding bird species detected in 247 pairs of point counts. For each pair of points one count was conducted in primary forests (open circles) and one count was conducted in secondary forests (solid circles).

estimated EDRs were lower in primary forests than in secondary forests.

Species specific comparisons using density estimates derived from Program DISTANCE showed three bird species (Winter Wren, Black-throated Blue Warbler, and Dark-eyed Junco) were significantly more abundant in primary forests compared with secondary forests and one bird species (Scarlet Tanager, Piranga olivacea) was significantly more abundant in secondary forests compared with primary forests (Fig. 3).

\subsection{Vegetation communities}

Vegetation structure, as measured by the number of trees in different size classes, showed differences between primary and secondary forests (Fig. 4a). While trees with a diameter at breast height $(\mathrm{dbh}) \leqslant 25 \mathrm{~cm}$ were similar for the two forest types, medium trees $(26-50 \mathrm{~cm} \mathrm{dbh})$ were significantly more abundant on secondary forest sites and large trees ( $>50 \mathrm{~cm} \mathrm{dbh}$ ) were significantly more abundant on primary forest sites.

Comparisons of per plot cover in the two communities revealed significantly higher canopy cover in secondary forests $(p<0.005)$, no difference in the subcanopy layer $(p>0.05)$, and significantly higher tall shrub cover in primary forests $(p<0.005)$. Standing snag densities were not significantly different between the two forest sites (155 standing snags on primary forest sites and 153 standing snags on secondary forest sites). However, the number of standing snags $>50 \mathrm{~cm} \mathrm{dbh}$ was significantly greater in the primary forest sample compared to the secondary forest sample $(p=0.005)$.

Tree species composition exhibited some significant differences between sites (Fig. 4(b)). We observed 50 tree species in the canopy on 233 paired vegetation plots. Ten tree species were limited to primary forest sites, 10 species were limited to secondary forest sites, and 30 species were common to
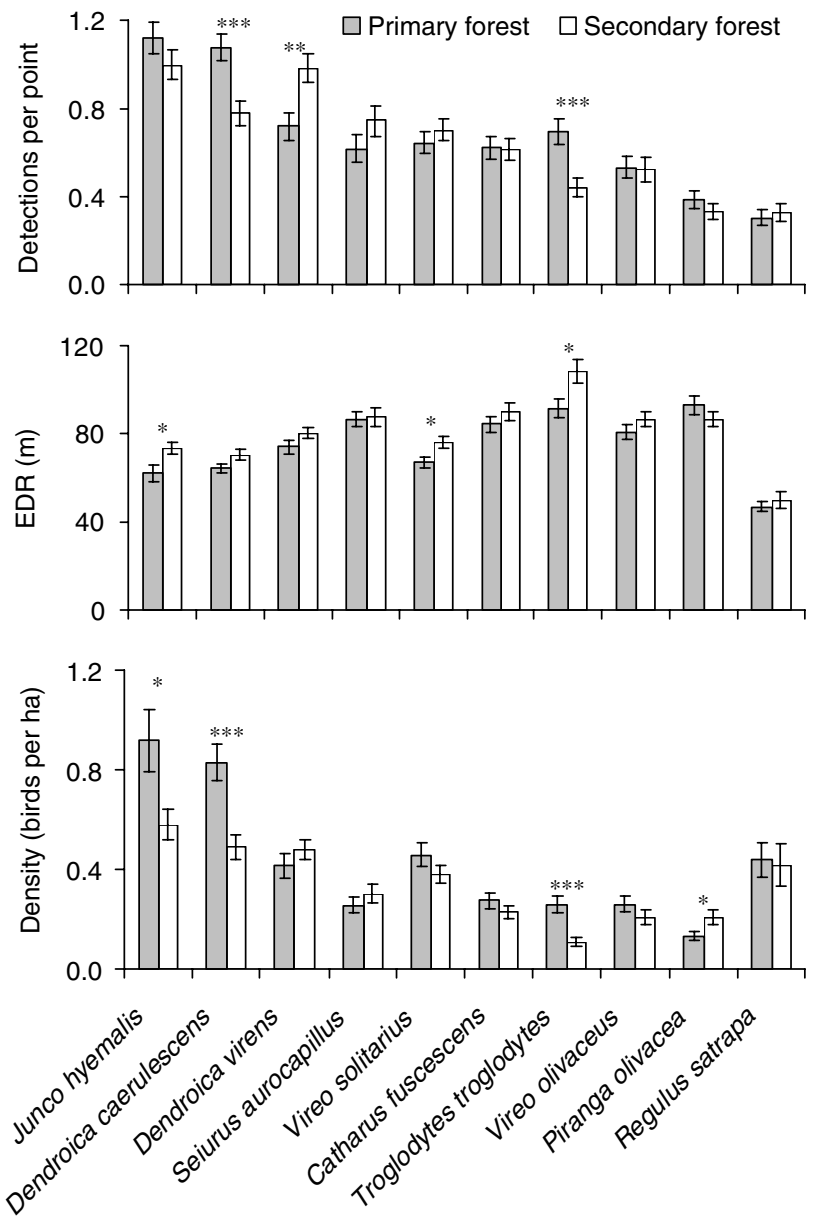

Fig. 3 - Comparisons of breeding birds recorded for 247 paired survey locations in primary and secondary forests. (Top) Mean relative abundance; counts are not adjusted for differences in detectability. (Middle) Effective detection radii (EDR) estimates (calculated using Program DISTANCE) for breeding bird species in primary and secondary forests. (Bottom) Estimated density of breeding birds in primary and secondary forests (calculated using Program DISTANCE). Error bars represent standard errors. Significant differences are denoted by asterisks $\left({ }^{*} p<0.05,{ }^{* *} p<0.01,{ }^{* * *} p<0.001\right)$.

both forest types. Four canopy species were significantly more abundant on primary forest sites (eastern hemlock [Tsuga canadensis], red oak [Quercus rubra], white oak [Quercus alba], and white pine [Pinus strobus]) and five species were significantly more common on secondary forest sites (yellow birch [Betula allaghaniensis], black birch [Betula lenta], American basswood [Tilia heterophylla], sugar maple [Acer saccharum], and pin cherry [Prunus pensylvatica]). Species composition patterns in the subcanopy and tall shrub layers were similar to the canopy, but with fewer significant differences. The subcanopy reflected differences in the canopy with eastern hemlock more abundant on primary forest sites and yellow birch more abundant on secondary forest sites. In the tall shrub layer, red oak, Rhododendron spp., and American chestnut ( $C$. dentata) were significantly more abundant on primary forest sites while yellow buckeye (Aesculus octandra) was more common on secondary forest sites. 

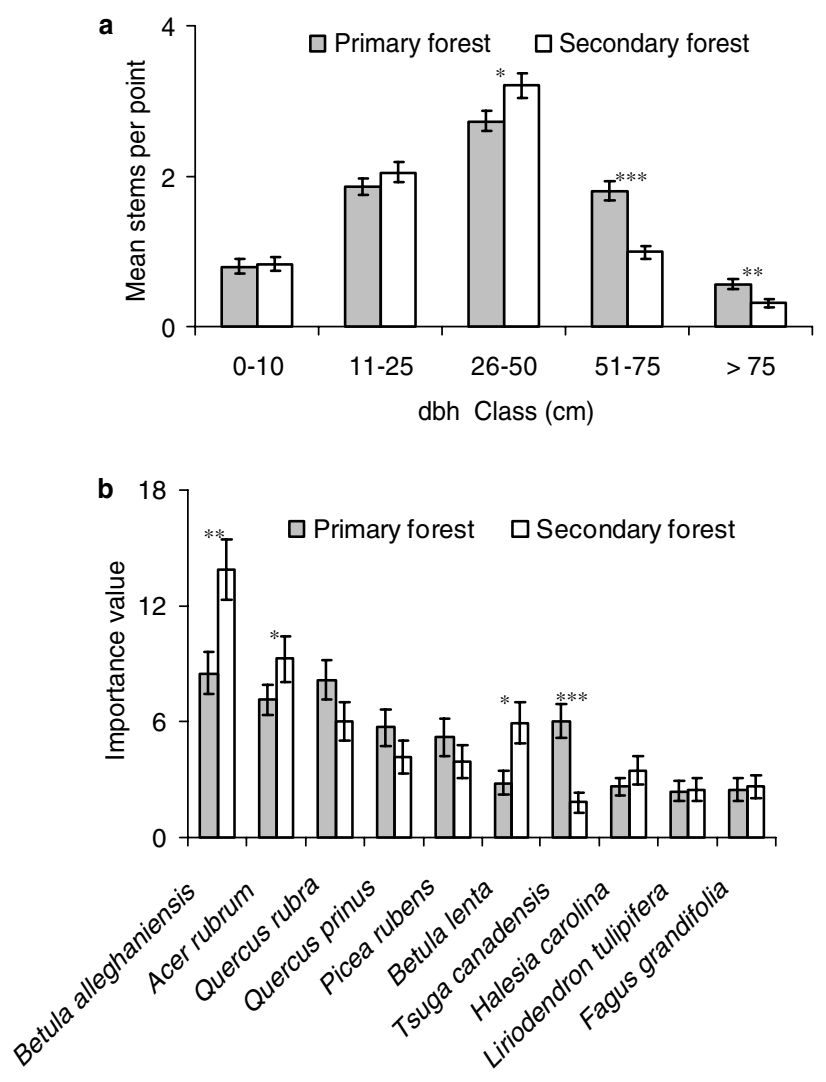

Fig. 4 - (a) Number of trees counted for five dbh classes. Data are from 191 paired survey plots in primary and secondary forests. (b) Mean importance values for tree species observed in 233 paired survey plots in primary and secondary forests. Significant differences are denoted by asterisks $\left({ }^{*} p<0.05,{ }^{* *} p<0.01,{ }^{* * *} p<0.001\right)$.

\section{Discussion}

Breeding bird and vegetation community structure were largely similar on primary forest and mature secondary forest 70 years after establishment of Great Smoky Mountains National Park. Primary and secondary forests shared 24 of the 25 most common bird species, as measured by number of detections (Appendix). Nonetheless, three breeding bird species (Winter Wren, Black-throated Blue Warbler, and Darkeyed Junco) showed significantly higher densities on primary forest sites than on closely paired secondary forest sites. Scarlet Tanagers were more abundant on secondary forest sites. The paucity of extensive tracts of similar primary forests in the American Southeast limits our knowledge of historic primary forest bird communities in this region. Differences in breeding bird density probably reflect habitat preferences linked to differences in vegetation characteristics on primary and secondary forest sites. The greater abundance of eastern hemlock on primary forest sites likely contributes to increased densities of Winter Wren at those sites because of the wren's preference for coniferous species (Hansen et al., 1995; Haney and Lydic, 1999). Similarly, the higher abundance of Rhododendron spp. in the tall shrub layer may have contributed to increased Black-throated Blue Warbler density on pri- mary forest sites due to its use of Rhododendron spp. as a foraging and nesting substrate (Holmes, 1994). Higher vegetation density in the tall shrub layer of primary forest sites may benefit those two species, as well as Dark-eyed Juncos, that prefer to nest and forage in lower vegetation strata. Likewise, higher canopy cover on secondary forest sites may explain higher Scarlet Tanager densities on those sites because the species prefers to nest and forage in closed-canopy forest (Mowbray, 1999).

Primary forest sites, as expected due to the age difference in the two forest types, had significantly more trees in large diameter at breast height (dbh) classes. Nonetheless, stem densities for smaller dbh classes were similar for primary and secondary forest sites, and we did not find a significant difference in the number of standing snags. Cover estimates for canopy, subcanopy, and tall shrub layers showed significantly higher canopy cover in secondary forests, no difference in the subcanopy layer, and significantly higher tall shrub cover in primary forests. Although we do not have tree fall gap data, these results may indicate more canopy openings in primary forests which could, in turn, result in higher cover estimates in the tall shrub layer of the forest. In general, these results are similar to those outlined in Ziegler's (2000) comparison of old-growth and mature second-growth hemlock-hardwood forests with the exception that we did not find a difference in snag density between the two sites. Primary forest sites had significantly higher importance values for late successional canopy species (eastern hemlock, red oak, white oak, and white pine) and significantly lower values for canopy species associated with intermediate successional forests (yellow birch, black birch, American basswood, and sugar maple). These compositional differences are similar to those identified by Latty et al. (2004) for old-growth and mature second-growth forests and also mirror Ziegler's (2000) finding of significantly higher densities of eastern hemlock on old-growth sites.

Stronger differences between undisturbed and disturbed habitats were identified in a study of salamander communities in Great Smoky Mountains National Park (Hyde and Simons, 2001). Two factors may explain the larger differences in salamander populations on these two forest types. First, differences in the size and vagility of salamanders and birds suggests they may respond to habitat features at different spatial scales. Consequently, vegetation differences between undisturbed and disturbed forests in the park may occur at a scale relevant to salamanders, but below the resolution at which many breeding bird species select habitat. Second, salamanders and breeding birds respond to very different habitat features. Soil conditions and leaf litter characteristics are vital habitat features for salamanders, while vegetation structure is a key habitat feature for most breeding forest birds. Although we lack soil and leaf litter data for our study site, Latty et al. (2004) showed that differences in soil characteristics persist nearly 100 years after selective logging in northern hardwood forests.

The differing results for bird and salamander communities in primary and secondary forests in Great Smoky Mountains National Park have important management implications for resource managers who rely on indicator taxa to draw inferences about other species or communities. While breeding birds are more readily sampled than salamanders, breeding 
birds may not be adequate indicators of forest condition for species that are potentially more sensitive to fine scale habitat features. Similarly, vegetation data should be accompanied by information about soil characteristics in discriminating between primary and secondary forests. These results add strength to the recommendations of Rolstad et al. (2002) who stress the importance of identifying appropriate structural features in the identification of old-growth and suggest that dispersal-limited species may be better indicators of old-growth forests than more vagile species.

The differences in our bird community results for unadjusted point count data and density estimates which accounted for differences in detection probabilities underscore the importance of using methods that estimate detection probabilities in different sampling units. Had we not adjusted our point transect data to account for differential probabilities of detection in primary and secondary forests, we would have missed the significant difference in densities for Dark-eyed Junco and erroneously reported a significant difference for Black-throated Green Warbler. Both of these species exhibited lower effective detection radii (EDR) in primary forests compared with secondary forests, effectively increasing the community differences for Dark-eyed Juncos and decreasing the differences for Black-throated Green Warblers. Failure to account for such differences in detection probabilities in different sampling units, such as primary and secondary forests, weakens inferences from comparative studies (Yoccoz et al., 2001; Pollock et al., 2002).

Our results indicate that measures of bird abundance in southern Appalachian forests should be adjusted for differences in detection probability associated with both bird species and habitat types. Nine of the 10 most common species in this study had lower EDRs in primary forests, suggesting reduced detection probabilities in primary forest for common forest bird species. Differences in detection probability may reflect differences in vegetation structure. For example, the dense tall shrub forest layer may have reduced observers' ability to hear distant birds on primary forest sites. Likewise the dense canopy layer on secondary forest sites may explain why EDRs for Scarlet Tanagers were lower on secondary forest sites. Fixed radius plots, scaled to reduce differences in detection probability among species or habitats, can reduce sampling bias, but often at the cost of reduced sample size and lower statistical power. Alternatively, detection probabilities can also vary with bird density (Bart and Schoultz, 1984).
Although bird and vegetation communities on primary and mature secondary forest in Great Smoky Mountains National Park are currently similar, some breeding bird species still differentiate between the two forest types, and some differences in vegetation structure and composition remain. These results suggest that forests logged 70-100 years ago have substantially recovered as habitat for most forest songbirds, but several caveats must be considered. First, there is no way to determine if the remaining primary forest sites are representative of historic primary forest conditions, because most of the primary forest remaining in the eastern United States survives on steep, high elevation slopes that were inaccessible to loggers. Second, results for the bird community cannot be generalized to other species, such as salamanders, that respond to different habitat features and which may respond at different spatial and temporal scales. Third, the bird communities on undisturbed and previously logged sites in Great Smoky Mountains National Park may be more similar today than those on more fragmented landscapes because many secondary forest sites in the park are contiguous with large patches of undisturbed forest. The proximity of logged sites to extensive tracts of primary forest may have buffered the effects of disturbance, if the primary forest sites served as population sources for regenerating habitats. Coarse-scale island biogeographic (MacArthur and Wilson, 1967; Newton, 1995) and population source-sink (Robinson et al., 1995) relationships are well established for bird populations. At a finer scale, the putative role source areas for birds (Simons et al., 2000; Brotons et al., 2003) and plants (Duffy and Meier, 1992; Matlack, 1994) play in the colonization of regenerating habitats, has proven difficult to verify. Finally, because our findings are based on abundance measures, our comparisons ignore potentially important differences in the survival and fecundity of populations (Van Horne, 1983).

\section{Acknowledgements}

We thank the many field assistants who made this work possible. We also thank Keith Langdon, Chuck Parker, Carroll Schell, Bob Dellinger, and Michael Kunze of Great Smoky Mountains National Park for logistical and technical support. The Friends of Great Smoky Mountains National Park, the National Park Service, and the USGS funded this research.

\section{Appendix - Number of detections of breeding bird species observed in paired primary and secondary forest sites ( $N=247$ pairs). Species are in descending order of commonness, as measured by number of detections (unadjusted for detectability).}

\begin{tabular}{llcc}
\hline Common name & Scientific name & Primary forest & Secondary forest \\
\hline Dark-eyed Junco & Junco hyemalis & 277 & 247 \\
Black-throated Blue Warbler & Dendroica caerulescens & 266 & 192 \\
Black-throated Green Warbler & Dendroica virens & 178 & 243 \\
Ovenbird & Seiurus aurocapillus & 153 & 184 \\
Blue-headed Vireo & Vireo solitarius & 159 & 174 \\
Veery & Catharus fuscescens & 154 & 152
\end{tabular}


Appendix - continued

\begin{tabular}{|c|c|c|c|}
\hline Common name & Scientific name & Primary forest & Secondary forest \\
\hline Winter Wren & Troglodytes troglodytes & 172 & 109 \\
\hline Red-eyed Vireo & Vireo olivaceus & 132 & 129 \\
\hline Scarlet Tanager & Piranga olivacea & 95 & 82 \\
\hline Golden-crowned Kinglet & Regulus satrapa & 75 & 81 \\
\hline Red-breasted Nuthatch & Sitta canadensis & 64 & 47 \\
\hline Canada Warbler & Wilsonia canadensis & 56 & 52 \\
\hline Black-capped Chickadee & Poecile atricapilla & 44 & 49 \\
\hline Black-and-white Warbler & Mniotilta varia & 44 & 45 \\
\hline Brown Creeper & Certhia americana & 36 & 48 \\
\hline Hooded Warbler & Wilsonia citrina & 38 & 43 \\
\hline Northern Parula & Parula americana & 41 & 35 \\
\hline Chestnut-sided Warbler & Dendroica pensylvanica & 42 & 27 \\
\hline Eastern Towhee & Pipilo erythrophthalmus & 33 & 35 \\
\hline Pileated Woodpecker & Dryocopus pileatus & 26 & 35 \\
\hline Chimney Swift & Chaetura pelagica & 42 & 18 \\
\hline Blackburnian Warbler & Dendroica fusca & 34 & 22 \\
\hline American Crow & Corvus brachyrhynchos & 26 & 29 \\
\hline Blue Jay & Cyanocitta cristata & 26 & 25 \\
\hline Tufted Titmouse & Baeolophus bicolor & 24 & 26 \\
\hline Hairy Woodpecker & Picoides villosus & 15 & 26 \\
\hline Rose-breasted Grosbeak & Pheucticus ludovicianus & 20 & 10 \\
\hline Indigo Bunting & Passerina cyanea & 8 & 22 \\
\hline Wood Thrush & Hylocichla mustelina & 9 & 18 \\
\hline Acadian Flycatcher & Empidonax virescens & 12 & 14 \\
\hline White-Breasted Nuthatch & Sitta carolinensis & 10 & 15 \\
\hline Worm-eating Warbler & Helmitheros vermivorus & 6 & 15 \\
\hline Common Raven & Corvus corax & 10 & 5 \\
\hline Eastern Wood-Peewee & Contopus virens & 9 & 8 \\
\hline Downy Woodpecker & Picoides pubescens & 9 & 4 \\
\hline Carolina Chickadee & Poecile carolinensis & 8 & 8 \\
\hline Carolina Wren & Thyrothorus ludovicianus & 4 & 12 \\
\hline American Robin & Turdus migratorius & 7 & 4 \\
\hline Pine Siskin & Carduelis pinus & 7 & 3 \\
\hline Cedar Waxwing & Bombycilla cedrorum & 4 & 6 \\
\hline Gray Catbird & Dumetella carolinensis & 3 & 7 \\
\hline American Goldfinch & Carduelis tristis & 2 & 6 \\
\hline Yellow-billed Cuckoo & Coccyzus americanus & 3 & 4 \\
\hline Brown Thrasher & Toxostoma rufum & 3 & 2 \\
\hline Broad-winged Hawk & Buteo platypterus & 3 & 1 \\
\hline Ruby-throated Hummingbird & Archilochus colubris & 2 & 2 \\
\hline Red Crossbill & Loxia curvirostra & 2 & 2 \\
\hline Ruffed Grouse & Bonasa umbellus & 2 & 2 \\
\hline Northern Flicker & Colaptes auratus & 1 & 3 \\
\hline Wild Turkey & Meleagris gallopavo & 2 & 1 \\
\hline Yellow-throated Warbler & Dendroica dominica & 2 & 1 \\
\hline Northern Cardinal & Cardinalis cardinalis & 0 & 3 \\
\hline Purple Finch & Carpodacus purpureus & 0 & 3 \\
\hline Red-bellied Woodpecker & Melanerpes carolinus & 2 & 0 \\
\hline American Redstart & Setophaga ruticilla & 1 & 1 \\
\hline Eastern Phoebe & Sayornis phoebe & 1 & 1 \\
\hline Yellow-throated Vireo & Vireo flavifrons & 1 & 1 \\
\hline Louisiana Waterthrush & Seiurus motacilla & 0 & 2 \\
\hline Blue-gray Gnatcatcher & Polioptila caerulea & 0 & 2 \\
\hline Red-tailed Hawk & Buteo jamaicensis & 1 & 0 \\
\hline Brown-headed Cowbird & Molothrus ater & 0 & $\begin{array}{c}1 \\
\text { inued on next page) }\end{array}$ \\
\hline
\end{tabular}




\section{Appendix - continued}

\begin{tabular}{llcc}
\hline Common name & Scientific name & Primary forest & Secondary forest \\
\hline Great Crested Flycatcher & Myiarchus crinitus & 0 & 1 \\
Barred Owl & Strix varia & 0 & 1 \\
Mourning Dove & Zenaida macroura & 0 & 1 \\
Swainson's Warbler & Limnothlypis swainsonii & 0 & 1 \\
Eastern Screech-owl & Otus asio & 0 & 1 \\
Summer Tanager & Piranga rubra & 0 & 1 \\
Saw-whet Owl & Aegolius funereus & 0 & 1 \\
\hline
\end{tabular}

\section{R E F E R E N C E S}

Avery, T.E., Burkhart, H.E., 1983. Forest Measurements. McGraw Hill, New York.

Bart, J., Schoultz, J.D., 1984. Reliability of singing bird surveys: changes in observer efficiency with avian density. Auk 101, 307-318.

Blake, J.G., Loiselle, B.A., 2001. Bird assemblages in second-growth and old-growth forests, Costa Rica: perspectives from mist nets and point counts. Auk 118, 304-326.

Boulinier, T., Nichols, J.D., Hines, J.E., Sauer, J.R., Flather, C.H., Pollock, K.H., 2001. Forest fragmentation and bird community dynamics: inferences at regional scales. Ecology 82, 1159-1169.

Brotons, L., Monkkonen, M., Huhta, E., Nikula, A., Rajasarkka, A., 2003. Effects of landscape structure and forest reserve location on old-growth forest bird species in Northern Finland. Landscape Ecology 18, 377-393.

Buckland, S.T., Anderson, D.R., Burnham, K.P., Laake, J.L., 1993. Distance Sampling: Estimating Abundance of Biological Populations. Chapman and Hall, New York.

Busing, R.T., 1998. Composition, structure and diversity of cove forest stands in the Great Smoky Mountains: a patch dynamics perspective. Journal of Vegetation Science 9, 881-890.

Davis, M.B., 1996. Extent and location. In: Davis, M.B. (Ed.), Eastern Old-Growth Forests: Prospects for Rediscovery and Recovery. Island Press, Washington, DC, pp. 18-32.

Diaz, I.A., Armesto, J.J., Reid, S., Sieving, K.E., Wilson, M.F., 2005. Linking forest structure and composition: avian diversity in successional forests of Chiloe Island, Chile. Biological Conservation 123, 91-101.

Duffy, D.C., Meier, A.J., 1992. Do Appalachian herbaceous understories ever recover from clearcutting? Conservation Biology 6, 196-201.

Greenberg, C.H., McNab, W.H., 1998. Forest disturbance in hurricane-related downbursts in the Appalachian mountains of North Carolina. Forest Ecology and Management 104, 179-191.

Haney, J.C., 1999. Hierarchical comparisons of breeding birds in old-growth conifer-hardwood forest on the Appalachian Plateau. Wilson Bulletin 111, 89-99.

Haney, J.C., Lydic, J., 1999. Avifauna and vegetation structure in an old-growth oak-pine forest on the Cumberland Plateau, Tennessee (USA). Natural Areas Journal 19, 199-210.

Haney, J.C., Lee, D.S., Wilbert, M., 2001. A half-century comparison of breeding birds in the southern Appalachians. Condor 103, 268-277.

Hansen, A.J., McComb, W.C., Vega, R., Raphael, M.G., Hunter, M., 1995. Bird habitat relationships in natural and managed forests in the west cascades of Oregon. Ecological Applications 5, 555-569.

Herbeck, L.A., Larsen, D.R., 1999. Plethodontid salamander response to silvicultural practices in Missouri Ozark forests. Conservation Biology 13, 623-632.
Holmes, R.T., 1994. Black-throated Blue Warbler (Dendroica caerulescens). The Birds of North America. Number 87. The Academy of Natural Sciences, Philadelphia. and The American Ornithologists' Union, Washington, D.C.

Hyde, E.J., Simons, T.R., 2001. Sampling Plethodontid salamanders: sources of variability. Journal of Wildlife Management 65, 624-632.

Johnson, K.D., Hain, F.P., Johnson, K.S., Hastings, F., 2000. Hemlock resources at risk in the Great Smoky Mountains National Park, In: McManus, K.A., Shields, K.S., Souto, D.R. (Eds), Proceedings: Symposium on Sustainable Management of Hemlock Ecosystems in Eastern North America. US Department of Agriculture, Forest Service, General Technical Report NE-267, Newtown Square, Pennsylvania, pp. 111-112.

Jung, T.S., Thompson, I.D., Titman, R.D., Applejohn, A.P., 1999. Habitat selection by forest bats in relation to mixed-wood stand types and structure in central Ontario. Journal of Wildlife Management 63, 1306-1319.

Laake, J.L., Buckland, S.T., Anderson, A.D., Burnham, K.P., 1993. DISTANCE User's Guide. Colorado Cooperative Fish \& Wildlife Research Unit, Colorado State University, Fort Collins, Colorado.

Lancia, R.A., Nichols, J.D., Pollock, K.H., 1994. Estimating the number of animals in wildlife populations. In: Houkhout, T.A. (Ed.), Research and Management Techniques for Wildlife and Habitats, fifth ed. The Wildlife Society, Bethesda, MD, pp. 215-253.

Latty, E.F., Canham, C.D., Marks, P.L., 2004. The effects of land-use history on soil properties and nutrient dynamics in northern hardwood forests of the Adirondack mountains. Ecosystems 7, 193-207.

Leverett, R., 1996. Definitions and history. In: Davis, M.B. (Ed.), Eastern Old-Growth Forests: Prospects for Rediscovery an Recovery. Island Press, Washington, DC, pp. 3-17.

Liebhold, A.M., MacDonald, W.L., Bergdahl, D., Mastro, V.C., 1995. Invasion by exotic forest pests: a threat to forest ecosystems. Forest Science Monographs 30, 1-49.

Lomolino, M.V., Perault, D.R., 2000. Assembly and disassembly of mammal communities in a fragmented temperate rain forest. Ecology 81, 1517-1532.

Luck, G.W., 2002. The habitat requirements of the rufous treecreeper (Climacteris rufa). 1. Preferential habitat use demonstrated at multiple spatial scales. Biological Conservation 105, 383-394.

MacArthur, R.H., Wilson, E.O., 1967. The Theory of Island Biogeography. Princeton University Press, Princeton, NJ.

Magurran, A.E., 1988. Ecological Diversity and its Measurement. Princeton University Press, Princeton, NJ.

Martikainen, P., Siitonen, J., Punttila, P., Kaila, L., Rauh, J., 2000 Species richness of Coleoptera in mature and old-growth boreal forests in southern Finland. Biological Conservation 94, 199-209.

Matlack, G.R., 1994. Plant species migration in a mixed-history forest landscape in eastern North America. Ecology 75, 1491-1502. 
Morrison, M.L., 1992. Bird abundance in forests managed for timber and wildlife resources. Biological Conservation 60, 127-134.

Mowbray, T.B., 1999. Scarlet Tanager (Piranga olivacea). The Birds of North America. Number 479. The Academy of Natural Sciences, Philadelphia. and American Ornithologists' Union, Washington, DC.

Newton, I., 1995. The contribution of some recent research on birds to ecological understanding. Journal of Animal Ecology 64, 675-696.

Okland, B., 1996. Unlogged forests: important sites for preserving the diversity of mycetophilids (Diptera: Sciaroidea). Biological Conservation 76, 297-310.

Pollock, K.H., Nichols, J.D., Simons, T.R., Farnsworth, G.L., Bailey, L.L., Sauer, J.R., 2002. Large scale wildlife monitoring studies: statistical methods for design and analysis. Environmetrics 13, 105-111.

Pyle, C., 1985. Vegetation disturbance history of Great Smoky Mountains National Park: an analysis of archival maps and records. USDI National Park Service Research/Resources Management Report SER-77. Great Smoky Mountains National Park, Gatlinburg.

Ralph, J.C., Droege, S., Sauer, J.R., 1995. Managing and monitoring birds using point counts: standards and applications. In: Ralph, J.C., Sauer, J.R., Droege, S. (Eds.), Monitoring Bird Populations by Point Counts). United States Forest Service General Technical Report PSW-GTR-149, pp. 161-168.

Reynolds, R.T., Scott, J.M., Nussbaum, R.A., 1980. A variable circular-plot method for estimating bird numbers. Condor 82, 309-313.

Robinson, S.K., Thompson III, F.R., Donovan, T.M., Whitehead, D.R., Faaborg, J., 1995. Regional forest fragmentation and the nesting success of migratory birds. Science 267, 1987-1990.

Rolstad, J., Gjerde, I., Gundersen, V.S., Sætersdal, M., 2002. Use of indicator species to assess forest continuity: a critique. Conservation Biology 16, 253-257.

Rosenstock, S.S., Anderson, D.R., Giesen, K.M., Leukering, T., Carter, M.F., 2002. Landbird counting techniques: current practices and an alternative. Auk 119, 46-53.

Runkle, J.R., 2000. Canopy tree turnover in old-growth mesic forests of eastern North America. Ecology 81, 554-567.

Sallabanks, R., Arnett, E.B., Marzluff, J.M., 2000. An evaluation of research on the effects of timber harvest on bird populations. Wildlife Society Bulletin 28, 1144-1155.

SAMAB, 1996 (Southern Appalachian Man and the Biosphere), 1996. The southern Appalachian Assessment terrestrial technical report. Report 5 of 5. US Department of Agriculture, Forest Service, Southern Region, Atlanta, Georgia.

Schuler, T.M., Gillespie, A.R., 2000. Temporal patterns of woody species diversity in a central Appalachian forest from 1856 to 1997. Journal of the Torrey Botanical Society 127, 149-161.
Shriner, S.A., 2001. Distribution of breeding birds in Great Smoky Mountains National Park. Ph.D. dissertation, Department of Zoology, North Carolina State University, Raleigh, NC.

Shriner, S.A., Simons, T.R., Farnsworth, G.L., 2002. Modeling habitat associations of breeding birds in Great Smoky Mountains National Park. In: Scott, J.M. et al. (Eds.), Predicting Species Occurrences: Issues of Scale and Accuracy. Island Press, pp. 529-535.

Simons, T.R., Farnsworth, G.L., Shriner, S.A., 2000. Evaluating Great Smoky Mountains National Park as a population source for the Wood Thrush. Conservation Biology 14, 1133-1144.

Suorsa, P., Huhta, E., Jantti, A., Nikula, A., Helle, H., Kuitunen, M., Kiovunen, V., Hakkarainen, H., 2005. Thresholds in selection of breeding habitat by the Eurasian treecreeper (Certhia familiaris). Biological Conservation 121, 443-452.

Thomas, L., Laake, J.L., Derry, J.F., Buckland, S.T., Borchers, D.L., Anderson, D.R., Burnham, K.P., Strindberg, S., Hedley, S.L., Burt, M.L., Marques, F.F.C., Pollard, J.H., Fewster, R.M., 1998. Distance 3.5 Research Unit for Wildlife Population Assessment. University of St. Andrews, UK. Available from: $<$ http//www.ruwpa.st-and.ac.uk/distance/>.

Thompson, W.L., White, G.C., Gowan, C., 1998. Monitoring Vertebrate Populations. Academic Press, San Diego, CA.

Thompson, I.D., Hogan, H.A., Montevecchi, W.A., 1999. Avian communities of mature balsam fire forests in Newfoundland: age-dependence and implications for timber harvesting. Condor 101, 311-323.

Thompson, I.D., Baker, J.A., Ter-Mikaelian, M., 2003. A review of the long-term effects of post-harvest silviculture on vertebrate wildlife, and predictive models, with an emphasis on boreal forests in Ontario, Canada. Forest Ecology and Management 177, 441-469.

Van Horne, B., 1983. Density as a misleading indicator of habitat quality. Journal of Wildlife Management 47, 893-901.

White, P.S., White, R.D., 1996. Old-growth oak and oak-hickory forests. In: Davis, M.B. (Ed.), Eastern Old-Growth Forests: Prospects for Rediscovery and Recovery. Island Press, Washington, DC, pp. 178-198.

Yarnell, S.L., 1998. The southern Appalachians: a history of the landscape. US Department of Agriculture, Forest Service, General Technical Report SRS-18, Asheville, NC.

Yoccoz, N.G., Nichols, J.D., Boulinier, T., 2001. Monitoring of biological diversity in space and time. Trends in Ecology and Evolution 16, 446-453.

Zar, J.H., 1999. Biostatistical Analysis, fourth ed. Prentice-Hall, Inc., Upper Saddle River, NJ.

Ziegler, S.S., 2000. A comparison of structural characteristics between old-growth and postfire second-growth hemlock-hardwood forests in Adirondack Park, New York, USA. Global Ecology and Biogeography 9, 373-389. 